\title{
Beyond Liberation: Conceptualizations of History at the Canadian Lesbian and Gay Archives
}

\author{
Danielle Cooper, York University
}

\section{Introduction}

In 1977, the first issue of the Canadian Gay Archives' (CGA) newsletter, Gay Archivist, was published and included the section, "Problems With Research in Gay History." The section identified both gay history's "problems" and provided solutions:

Where does one begin to search out such history? The answer is simply everywhere. Gay people have always existed, and wherever there is recorded history, we may expect to find glimpses of them. It has often been the case that even where gay history has been uncovered by either non-gay or gay historians, it has been suppressed or ignored. ${ }^{1}$

Gay Archivist's solution - to find gay history "everywhere" - not only reflected the newsletter's assumption of a stable and cohesive gay identity across time, but also its underlying hope that gay history would become a project without bounds.

By the eleventh issue of the recently re-named Lesbian and Gay Archivist distributed in 1995, however, gay history's overabundance had become a problem for the archives. The newsletter's name-change reflected the archives' namechange to Canadian Lesbian and Gay Archives (CLGA) in 1993. In the section, "Keeping Our Stories Alive" the newsletter stated that "the rapid growth of the holdings, changing technology, and the increasingly diverse demands of researchers... have placed pressures on volunteers and on our funding base."2 Rapid growth necessitated a turn inwards towards focusing on organizational concerns: the newsletter no longer found lesbian and gay history "everywhere," but rather, focused attention on the archives' holdings, current activities, and future plans. A corollary to the newsletter's inward focus was a change in assumptions about gay history and gayness in general: these concepts were no longer transhistorically expansive and worthy of exploration, but rather, stable terms that the organization was specifically mandated towards collecting as they manifested in a specific geographic area and time period.

This paper examines the CGA/CLGA's conceptualization of history through the organization's publication Gay Archivist's/Lesbian and Gay Archivist's in the issues spanning from 1977 to 1995 . My major research questions include: what did the newsletter identify as the purpose of history and how did its con- 
tributors think this history should be done? When did the newsletter locate the beginning of this history? Which individuals and events did the newsletter include in these narratives? My findings, titled "Lesbian and Gay Canadian History," "Reconstruction and Recovery," "Beyond Liberation," and "The Turn Inwards" trace how the newsletter represented and actively constructed lesbian and gay history and link these conceptualizations to the archives' and LGBT history's development more broadly.

Located in Toronto, Ontario, Canada, the CLGA's current mandate is to "acquire, preserve, organize, and give public access to information and materials in any medium, by and about LGBT people, primarily produced in or concerning Canada." 3 The archives were originally founded by activists as the Canadian Gay Liberation Movement Archives in 1973 as a repository for The Body Politic, a monthly gay liberation magazine that ran from 1971 to 1987. The Canadian Gay Liberation Movement Archives' was renamed the Canadian Gay Archives in 1977 and then again renamed the Canadian Lesbian and Gay Archives in 1993. This will be discussed in my subsequent findings, that these name changes reflect the archives' orientation towards and the evolution of LGBT politics during this period. In addition to collecting The Body Politic and other content associated with the gay liberation movement the archives took a "total archives" approach early in its inception by collecting a variety of texts and objects of relevance to LGBT life and research focusing primarily on Canada but also internationally including: papers of individuals and organisations, over 8,800 international LGBT serial titles from the 1930s onwards, vertical files for reference purposes, an audio collection, ephemera including matchbooks, banners and buttons, and a library. ${ }^{4}$

In contrast to mainstream archives that are located in institutional contexts such as universities or government repositories, the CLGA is an autonomous, grassroots, primarily volunteer-run entity. As such, the CLGA is part of a larger legacy of LGBT grassroots archives in the United States and Canada and was created in response to the disinterest and deliberate acts of information erasure attributable to institutionalized homophobia. ${ }^{5}$ These early LGBT archives in the United States and Canada emerged in conjunction with homophile and gay liberation movement activity as organisations for and by gay and lesbian communities. ${ }^{6}$ In addition to the CLGA, other LGBT archives from this period include the Lesbian Herstory Archives in Brooklyn, New York, the June Mazer Archives and ONE Gay and Lesbian Archives, both located in Los Angeles California.

Taking into consideration that LGBT grassroots archives like the CLGA are major information sources for LGBT histories, we need a better understanding of how these organisations defined, and, by extension, how they have shaped the LGBT historical record over time. My findings highlight not only how Gay Archivist/Lesbian and Gay Archivist constructed a specifically "lesbian and gay" history, but also how the representation and construction of this 
history shifted with the archives' changing mandate. This paper, therefore, invites historians, information scholars and professionals to think of LGBT grassroots archives not as passive repositories, but rather as active agents.

\section{Notes on the Source Material and Terminology}

The archives' newsletter, Gay Archivist/Lesbian and Gay Archivist, is a rich source for understanding the archives' conceptualization of history because it was the archives' major venue for self-promotion and communication. In addition to reviewing the newsletter, I also consulted newspaper articles written about the archives in The Body Politic because the articles served a similar promotional function. The archives distributed its newsletter in person and by mail primarily to members, supporters and other interested organisations and they often traded their newsletter with gay and lesbian periodicals from other organisations . ${ }^{7}$

The archives also sent out their newsletter to Library and Archives Canada and other archives and history groups with similar mandates to their own. ${ }^{8}$ In addition, they distributed the newsletter at gay and lesbian events and conferences and at several local bookstores, and they sometimes "piggy backed" with other supportive organisations, like Casey House, to reach a wider audience. ${ }^{9}$ Although it is notoriously difficult to calculate organizational newsletter circulation, factoring in the growth of the archives over time, I estimate that the archives' newsletter circulation initially ranged from about two to three hundred copies per issue in the 1970s and exceeded one thousand copies by the early 1990s. ${ }^{10}$

The archives published the newsletter from 1977 to 2005 on a roughly annual or biannual basis with a few longer gaps between some issues (i.e. the five year gap between issue four in 1981 and issue five in 1986). The issues became increasingly lengthy over time, ranging from about four pages in the 1970s and then expanding to about eight to ten from the 1980s onwards. Due to the scope of this paper and the complexities of doing "recent" history, I chose to concentrate my analysis on the newsletters from 1977 to 1995. Issue eleven in 1995 provided an appropriate cut-off point because the organization underwent a significant transition during the early to mid 1990s, not only by changing names to the CLGA in 1993 but also by initiating a major governance and mandate overhaul. ${ }^{11}$

Reflecting the fact that the archives and the newsletter underwent a name-change during the period I cover in this paper, I use the archives' and newsletter's names from the time under discussion. For example, when referring to the archives in 1989, I use "CGA" as opposed to "CLGA." At points where I want to refer to the newsletter as an entire corpus, I use "Gay Archivist/Lesbian and Gay Archivist." I chose this strategy because referring to period-appropriate 
names not only better reflects the specific contexts I studied but also draws our attention to the power of naming and re-naming.

\section{Lesbian and Gay History}

In contrast to contemporary notions of a "lesbian, gay, bisexual, transgendered, and queer/questioning" (LGBT) community, the CGA's primary mandate from 1977 to 1995 pertained to a Canadian lesbian and gay community and a Canadian lesbian and gay history. Gay Archivist from 1977 explained:

A conspiracy of silence has robbed lesbians and gay men of their history. This is no less true in Canada than elsewhere. A sense of continuity which derives from the knowledge of a heritage is essential for the building of self confidence in a community. ${ }^{12}$

The CGA not only believed in a cohesive Canadian lesbian and gay community in the present, but also that this community had a distinct and traceable past. As will be discussed later in this paper, the CGA invoked a broad, a-temporal concept of "gay" and "gay community" - that sometimes, such as in the case of the quote above, but not always included "lesbian" - to depoliticize the organization. This section, however, will focus on introducing how the CGA understood "lesbian and gay" and "Canadian" in relation to Canadian lesbian and gay history. Although Gay Archivist/Lesbian and Gay Archivist never defined "gay," "gay history" or "gay community," the newsletter's content suggests that the archives perceived the community as consisting primarily cis-gendered same-sex desiring men and women and believed that people in the past also conformed to these definitions. The newsletter favored historical content pertaining to gay men but also made a conscious effort, even in the earliest issues, to include lesbian content. The historical timeline section, "Recovery," from the 1981 issue devoted three out of the seven events featured to lesbian-specific events. ${ }^{13}$ This issue also noted that the CGA's fourth publication would be a list of the CGA's lesbian publication holdings and that the lesbian groups they contacted as part of their research had begun to send in missing issues so that the CGA could be the "national repository in Canada for all such material."14

The CGA's insistence on including lesbians in their conceptions of gay community and gay history is notable because the Canadian Women's Archives also existed in Toronto from 1972 to 1992. As Gay Archivist in 1978 acknowledged: "The Women's Archives, located in Toronto and operated by Pat Leslie of the Other Woman Collective, was visited in June, 1977. They have important material relating to Canadian lesbians." 15 'The CGA's collection and dissemination of historical information about lesbians, despite the overlap with The Women's Archives, reflects their understanding that "gay history" included lesbians. 
Although the Gay Archivist included lesbian historical content even in the earliest issues between 1977 and 1981, it is important to acknowledge that this coverage was less prevalent than the content pertaining to gay men. The 1990s, however, marked a period of increased attention to lesbian inclusion. As CLGA volunteer Barb explains in a volunteer profile from the newly re-named Lesbian and Gay Archivist in 1995:

I first discovered the Archives while reading one of its newsletters. I was fascinated by the historical materials covered in the issue but the articles seemed mostly for men. A few years later when I visited the Archives to donate some materials I noticed all of the valuable materials pertaining to lesbians past and present. I quickly made the decision to commit some time, my skills and my talents to helping this important organization. ${ }^{16}$

Barb's comment suggests that earlier issues of Gay Archivist created the impression that the archives' mandate was "mostly for men." Including Barb's perspective and changing the archives' and newsletter's name to "Lesbian and Gay," however, marked the archives increased interest in lesbian representation. Most notably, this increased interest in lesbian representation also coincided with The Women's Archives closure in 1992. The Women's Archives was a Toronto-based organised dedicated to collecting and preserving women's movement records from Canada. The Women's Archives' holdings were acquired by the University of Ottawa and renamed "The Canadian Women's Movement Archives."17

The Gay Archivist included very little content pertaining to people who were not exclusively same-sex desiring cisgender men and women. The following are some notable exceptions: The first issue in 1977 asked the question, "how prevalent was homosexuality and cross-dressing among Indians in what is now Canada?" in a list of gay history questions that "await answers."18 The newsletter's second issue noted that "R.B" had donated photographs and taped interviews of female impersonators from Club Manatee in the 1970 s. $^{19}$ Issue four's "Recovery" timeline also included the publication of By Grand Central Station I Sat Down and Wept in 1945, which, the newsletter notes, featured a bisexual character. $^{20}$

The presence, but extreme infrequency, of these inclusions suggests that although the CGA did not rule out the possibility that "gay community" extended beyond exclusively same-sex desiring cisgender people, the organization was also not particularly concerned with these groups. The CGA acknowledged this in issue four's section on "Public Accessibility" with the statement, "While the primary field of interest for the CGA is homosexuality, it actively collects material related to the following subjects: censorship, pornography, general attitudes to sexuality, transvestism, transsexualism, and the feminist movement."21 Although the CGA collected materials outside of their primary field of interest, Gay Archivist did not profile these materials or the history behind these materials 
to the same extent that the newsletter featured items and issues pertaining to "gay history."

Beyond "gay history" and "gay community," Gay Archivist also constructed a very specific concept of "Canadian" and Canadian-specific gay history. ${ }^{22}$ Throughout the period covered in this paper, Gay Archivist primarily featured Canadian historical content, which reflected the CGA's mandate to address a distinctly "Canadian" gay community and history. A major early exception was that one issue of Gay Archivist featured Magnus Hirschfeld, which will be discussed in more detail in the section of this paper entitled "Beyond Liberation." The CGA collected material beyond Canadian scope, however, but this content was primarily discussed in the newsletter in the present-tense, such as in features about recent periodical acquisitions or listings of other gay archives. ${ }^{23}$

The content in Gay Archivist portrayed "Canadian" as predominantly white and of European descent. The question quoted above, "how prevalent was homosexuality and cross-dressing among Indians in what is now Canada," is the only content pertaining to Indigenous people in the newsletter between 1977 and $1995 .^{24}$ In contrast, Gay Archivist profiled encounters between Canadians and prominent non-Canadian gay figures, such as when Walt Whitman visited Canada and when Charlotte Perkins Gilman gave a lecture in Canada. ${ }^{25}$ The Gay Archivist also regularly featured historical profiles about European-born men who engaged in same-sex activities in Canada prior to the twentieth centuries, such as Alexander Wood and George Markland. ${ }^{26}$ As highlighted in the following section, these unproblematized assumptions about who could be included among Canadian gay historical figures also echoes unproblematized assumptions about how history can be labeled as such.

\section{Reconstruction and Recovery}

In addition to delineating who and what constitutes 'gay' and 'Canadian', Gay Archivist also presented specific methodological approaches to gay history, which changed in tandem with the CGA. During the CGA's earliest phase, the newsletter initially emphasised that both "recording" and "reconstruction" - sometimes also referred to as "recovery" - were important approaches to gay historicizing. ${ }^{27}$ The first Gay Archivist issue in 1977 explained: "The gay community in Canada must take the responsibility of recording its more recent history, and must begin the serious research required to reconstruct the earlier history of gay people in this country." 28 While "recording" referred to the CGA's mandate to collect documents pertaining to gay life in Canada, "reconstruction" referred to research that uncovered previously suppressed or ignored "gay" content. This expressed interest in "reconstruction" enabled the newsletter to include Canadian "gay" historical information beyond the CGA's holdings (and what the CGA could easily collect). The newsletter's early interest in reconstruction, by 
extension, emphasised the newsletter's underlying ahistorical claim that "gay people have always existed, and wherever there is recorded history, we may expect to find glimpses of them."29

Echoing the previous section's findings, the predominant example of "reconstruction" themed evidence cited in the Gay Archivist's early issues were Canadian legal cases of men accused of same-sex activity prior to the twentieth century. The first issue discussed the recently rediscovered testimony of George Markland, an Inspector General of Upper Canada from the nineteenth century forced to resign over his alleged relations with young men in Toronto. ${ }^{30}$ The second issue's section on "Gays and New France" also offers three legal cases about sodomy from the sixteenth and seventeenth centuries. ${ }^{31}$ Issue three also notes that CGA volunteers were in the process of researching two other scandalous local figures from the eighteenth and nineteenth centuries, Alexander Wood (with no additional details about his "scandal") and Reverend Thomas Franchon, noted by the newsletter for having "sexual relations" with students at the school where he was President. ${ }^{32}$

Beyond pre-twentieth century Canadian sodomy cases, Gay Archivist also provided a section on "Recovery" in their 1981 issue, which offered evidence of gay-themed discourse, activities and individuals in Canada between 1872 and 1945. ${ }^{33}$ The content focused primarily on Canadian sources that address "gay" topics or include "gay" content, such as a book review in a Toronto magazine from 1872 that criticized Socrates' love of boys, and Canadian encounters with prominent "gay" figures, such as Charlotte Perkins Gilman's lecture in Toronto in 1919. Each event entry was cited from primary sources or biographies, which highlights that the content was literally "recovered" through careful reading. Two of the seven events highlighted in this section, furthermore, made reference to Walt Whitman, who is featured elsewhere in the same newsletter because the CGA also helped organize a "Whitman in Canada" conference the previous year. ${ }^{34}$

Both 1981's "Recovery" section and the Gay Archivist's early "reconstruction"-themed content emphasised that research is an important component of gay historical work and is therefore also relevant to the CGA. By highlighting those who did the research behind the "reconstruction"-based findings, these features emphasised the individual's role in gay history's construction. For example the 1977 feature on George Markland credited a "remarkable discovery" by Federal historian Robert Bums and 1978's section on "Gays in New France" acknowledged Quebec history student Jacques Briand. ${ }^{35}$ The Gay Archivist also noted reconstruction work done by CGA volunteers, including "continuing research" on Alexander Wood in 1979 and the role of the "archives' own research" in addition to the conference presentations about uncovering Walt Whitman's "true sexual identity."36 
The underlying theme of the Gay Archivist's reconstruction themed findings was the potential for and necessity of doing this type of research. Gay Archivist describes Robert Bums' George Markland discovery as "a recent case that is illustrative of the kinds of things we may yet expect to uncover." 37 The feature on "Gays in New France" also opens with "it has been our belief that much early gay history is yet to be uncovered" and ends with "we rely on people doing research across the country to watch for any references to gay people no matter how slight. These will often be very obscure. We will be grateful if they are brought to our attention." 38

The urgency and desire to find historical references to "gay people no matter how slight," however, also belies a transhistorical willingness by the early newsletters to construct gay history. The choice to title a section as "Gays and New France," for example, as opposed to "pre" or "proto" Gay France also reflects that content pertaining to reconstruction in the newsletter was often explicitly labeled as "gay" with no acknowledgement or exploration of the complexity of labeling individuals and activities that would not have been understood as such in their own contexts. In a few cases, however, reconstruction-themed content is discussed in terms of acts as opposed to gay identity. Issue three describes Reverend Thomas Franchon as having "sexual relations" with students at the school where he was president as opposed to being gay or even having gay sexual relations. ${ }^{39}$ Ultimately, the underlying choice to include content about "sexual relations" such as Franchon's in a section of a newsletter devoted to recovering gay history reflects the overwhelmingly ahistorical orientation of the newsletter that same-sex sexual activities can be labeled as gay regardless of the context in which the activities occurred.

\section{Beyond Liberation}

In addition to highlighting "reconstruction," Gay Archivist also created a broader definition of gay history that led to a de-emphasis of this history's political quality, both through past incidents included in this history and the role of historicizing in general. 1977's Gay Archivist included the following explanation for the CGA's name-change from Canadian Gay Liberation Movement Archives:

The name was changed to the Canadian Gay Archives, which seemed to better represent what the archives was attempting to do; to gather and preserve the history of gay men and lesbians in Canada, in addition to the gay liberation movement which had its beginnings in this country in 1969.40

When announcing the CGA's incorporation, the newsletter also discussed the CGA's status as politically "independent" in 1981:

In order to gain the support of as wide a spectrum of the community as possible, it was felt that the Archives should be independent of any 
political organization. In terms of fundraising, incorporation was seen as the first step toward achieving "charitable status" with Revenue Canada. To this end it was necessary to show clearly that the Archives was not itself political. ${ }^{41}$

As the comments above highlight, the newsletter articles from 1977 to 1981 particularly highlight the CGA's distance from politics. During this period, CGA began the process of gaining autonomy from The Body Politic and Pink Triangle Press (PTP). In 1978, the police raided the CGA along with the PTP offices and the CGA determined that becoming autonomous and "showing[ing] clearly that Archives was not itself political" was the best strategy for preventing future raids. ${ }^{42}$

Gay Archivist featured information pertaining to gay activism during this period; however, this information was generally geared toward highlighting the CGA's ongoing acquisitions, as opposed to providing historical interpretation, like the earlier "reconstruction" features. One notable exception to this is the first issue's inclusion of a small feature on Magnus Hirschfeld, " $80^{\text {th }}$

Anniversary," which reads: "May fifteenth marks the eightieth anniversary of the founding of the first activist gay organization. On that day in 1897 in Germany Magnus Hirschfield and four friends founded the Scientific-Humanitarian Committee."43 Recall, however, that in the same issue, Gay Archivist also included the feature, "Problems with Research on Gay History," which included the indepth story about Robert Bums' "incredible discovery" of George Markland. ${ }^{44}$

Beyond the conflict and incoherence surrounding the political nature of gay history, another possible explanation for the Gay Archivist's lack of historical interpretation pertaining to gay activism is that gay activism was too contemporary to be considered "historical." For example, Gay Archivist's first retrospective feature on gay activism, "Our Silver Anniversary," only appears in their 1989 issue. ${ }^{45}$ While many of the sources cited in the retrospective had been previously featured in archives under the auspices of acquisitions, "Our Silver Anniversary" represented the first time that these sources were gathered towards a comprehensive, historically reflexive piece. There was a similar time lag with Gay Archivist's coverage of AIDS: while the newsletter memorialized AIDS and devoted considerable content to the CGA's ever-growing collection as early as 1986, the newsletter did not provide comprehensive, retrospective content about the epidemic until "The Record of AIDS" in the 1992 issue. 46

Even when Gay Archivist included historical information pertaining to gay activism, the newsletter included the information to broaden the theme beyond liberation-style politics. "Our Silver Anniversary" opened by declaring, "Although the Stonewall riots of 1969 marked the symbolic founding of the modern gay liberation movement, several events in 1964 heralded the emergence of gays and lesbians as an organised force in Canada." As evidence of Canada's pre-Stonewall "organizing," this section not only discussed the "serious" 
newsletter by the Vancouver-based homophile association, ASK, but also the less "serious" Gay and TWO. 47 The 1979 feature on the CGA in The Body Politic, "Stashing the Evidence," also included a large image with an ASK newsletter alongside GAY and TWO covers. ${ }^{48}$ By grouping these periodicals together, the CGA conveyed that they had a broader definition of "organizing" that extended not only beyond the gay liberation movement but also beyond political movements in general. According to this definition, publishing gay content in any manifestation - including the less "serious" - constitutes organizing the gay community. Note, furthermore, Gay Archivist's use of the word "organizing," which pertained to any form of gathering as opposed to the expressly political.

\section{The Turn Inwards}

In 1995, Lesbian and Gay Archivist included a feature on Oscar Wilde entitled, "Out of the Archives." 49 The feature noted:

1995 marks the centenary of Oscar Wilde's incarceration on a charge of homosexual activity. Wilde spent two years in prison, where he wrote De Profundus and The Ballad of Reading Gaol...The Archives owns a number of books on Wilde, most having come from the library of Jim Egan.

Unlike earlier "reconstruction"-oriented features such as 1978's "Gays in New France" and 1981's "Recovery," "Out of the Archives" did not use any information from outside of the archives and did not include any historical interpretation. 50 "Out of the Archives," therefore, referred exclusively to highlighting the CLGA's holdings to the public, as opposed to the earlier "reconstruction"-oriented newsletter pieces, which focused on historical content beyond the CGA's collection.

The "Out of the Archives" feature reflects the archives' increasing "turn inwards" towards CGA-specific topics in Gay Archivist after the 1989 issue. From 1989's “Our Silver Anniversary” and onwards, Gay Archivist only included content about gay history as it directly pertained to the archives' collections. ${ }^{51}$ Gay Archivist from 1991, for instance, included "Remembering the Right to Privacy Commission" (RTPC), which provided a lengthy description of the RTPC's organizational history. ${ }^{52}$ The piece concludes by noting: "The Canadian Gay Archives has received several accessions of records created by the RTPC," which reflects the feature's purpose to highlight the archives' holdings. ${ }^{53}$

Similar to "Remembering the Right to Privacy Commission," 1991's Gay Archivist also included a long description of the Community Homophile Association of Toronto (CHAT) under the heading, "The Archivist at Work."54 This section provided a seven paragraph-long description of CHAT's organizational history, including the circumstances for the organization's formation and decline, the role of George Hislop in the organization, and the organization's 
notable activities. "The Archivist at Work" included CHAT's history as an example of the processing of records, and by extension, the "pleasures [of] producing finding aids that will lead the researcher to hitherto hidden nuggets of information." 55 Gay Archivist included CHAT's organizational history, therefore, as a means to discuss the archives' activities and holdings as opposed to providing information about gay history in general.

In addition to only including historical information that related to the CGA's activities and holdings, Gay Archivist's turn inwards is also reflected in the newsletter's increasing focus on the archives' current operations and future plans. For the first time in 1992, the newsletter included a description of the CGA's new governance structure, short features on the CGA's new Board members and the archives' budget table. ${ }^{56}$ Similarly, 1995's issue included the sections:

"Financial Goals," "Fundraising," and "Strategy for the Future." In this issue the CGA explained: "The reality is that the Archives, a wonderful community resource, has outgrown many past practices and former funding levels. New ideas, more money, and different approaches are all necessary for future success." 57

\section{Conclusion}

This paper focused specifically on how the CGA/CLGA's newsletter conceptualised and represented history as a topic over time. Further exploration of how the history of the CGA/CLGA as an organization more broadly fits within the larger context of LGBT social movements. Tom Warner's Never Going Back: A History of Queer Activism in Canada, for example, draws on source material from the CLGA but does not include the CLGA within the book's main narrative. ${ }^{58}$ Don McLeod's Lesbian and Gay Liberation in Canada includes entries about the precursor to the CLGA, the Canadian Gay Liberation Movement Archives; however, this book is designed as an annotated chronology, not a work of historical analysis. 59

The transition in Gay Archivist/Lesbian and Gay Archivist's focus on finding lesbian and gay history "everywhere" to focusing on collections and organizational concerns, as well as the newsletter's consistent construction of a Canadian lesbian and gay history with an apolitical stance reminds us how archives actively construct the history they keep. The organization's increasingly inwards stance echoes the evolution of the lesbian and gay movement, and later LGBT movement, towards abeyance and decline. In her discussion of scholarship on feminist archiving, Kate Eichhorn contends that studying archives associated with social movements is important because these archives are intimately connected to social movements' evolution, especially as a mechanism for maintenance when movements wane. ${ }^{60}$ This paper therefore takes up Eichhorn's observation that "sometimes an archive's story may be as important as its contents" as 
an invitation to begin to explore how CLGA's understood and represented its relationship to the LGBT movement in Canada. ${ }^{61}$

Ann Cvektovich warns us of the increasing importance of remembering LGBT grassroots archives and their "queer" strategies in the wake of the popularity of LGBT studies and the subsequent creation of institutionalized LGBT information collections. ${ }^{62}$ As this paper demonstrates, however, it is also important to develop a more nuanced understanding of these strategies and how they changed over time, "queer" or not. While Gay Archivist/Lesbian and Gay Archivist's methods of and overall interest in defining and locating lesbian and gay history changed over time, the newsletter privileged an initially transhistorical and consistently stable, normative focus on white, cisgender same sex desire as opposed to other LGBT and queer identities and activities such as those pertaining to BDSM, kink or transgender, to name just a few. Building on Lisa Duggan's conceptual framework, Gay Archivist/Lesbian and Gay Archivist reflects a tendency towards archival homonormativity that parallels the homonormativity that has pervaded the lesbian and gay movement and LGBT movement since the gay liberation era. ${ }^{63}$

\section{NOTES}

1 Canadian Gay Archives, "Problems With Research in Gay History," Gay Archivist No.1 (May 1977), accessed April 12, 2012, http:/ /www.clga.ca/aboutus/LGArchivist/v1.htm.

2 Canadian Lesbian and Gay Archives, "Keeping Our Stories Alive," Lesbian and Gay Archivist No. 11 (February 1995), accessed April 12, 2012, http://www.clga.ca/aboutus/LGArchivist/v11.htm.

3 Ibid.

${ }^{4}$ Don McLeod, "The Canadian Lesbian and Gay Archives, Research, and the Public," The Canadian Lesbian and Gay Archives, accessed February 28, 2014, http://www.clga.ca/research-and-public.

5 Although outside the scope of this paper it is important to acknowledge that LGBT archives also have an overlapping history with other grassroots LGBT information-based organizations including libraries, museums, and special collections. LGBT archives often also include other types of information collecting within their organizational mandates. In addition to an archive, the CLGA also contains the James Fraser Library and the National Portrait Collection. Kate Eichhorn, also observes that within feminist and queer studies "archive" is often used as an umbrella term to also denote libraries, museums, and special collections whereas the more professionally oriented library and information science 
discipline places strong emphasis on differentiating between these kinds of organizations.

6 The spectrum of LGBT archives is evolving considerably in terms of the organizational models and communities these organizations purport to serve. Some of these changes include: increased partnerships between LGBT grassroots archives and other institutions (ONE Archives, for example, is partnered with the University of Southern California and the June Mazer Lesbian Archives is partnered with the University of California, Los Angeles) and the creation of new LGBT archives within institutional contexts (for example, the Transgender Archives at the University of Victoria and the Archives of Lesbian Oral Testimony at Simon Fraser University, both in British Columbia, Canada).

7 Alan Miller, e-mail message to author, April 13, 2012.

8 Canadian Gay Archives, "Archives and History Projects," Gay Archivist No. 4 (September 1981), accessed April 14, 2012, http://www.clga.ca/aboutus/LGArchivist/v4.htm\#projects. This issue, for example, listed thirty-nine organizations and nineteen history projects under the section "Archives and History Projects." These organizations were gay and/or lesbian and/or feminist in orientation.

9 Alan Miller, e-mail message to author, April 13, 2012.

10 Marc Stein, e-mail message to author, April 16, 2012.

11 Canadian Gay Archives, "Fundraising," Gay Archivist No.10 (November 1992), accessed April 12, 2012, http://www.clga.ca/aboutus/LGArchivist/v10.htm. For example, in 1992 the CGA created a Board of Directors and initiated a new plan to radically restructure the archives' finances. The strategy included aggressive fundraising to offset the costs of the new location they moved into in 1992.

12 Canadian Gay Archives, "Problems with Research in Gay History."

13 Canadian Gay Archives, "Recovery,” Gay Archivist No. 4 (November 1981), accessed April 14, 2012. http://www.clga.ca/aboutus/LGArchivist/v4.htm\#projects.

14 Canadian Gay Archives, "Periodicals," Gay Archivist No. 4 (November 1981), accessed April 14, 2012. http://www.clga.ca/aboutus/LGArchivist/v4.htm\#projects.

15 Canadian Gay Archives, “Odds and Ends," Gay Archivist No. 2 (May 1978), accessed April 12, 2012, http://www.clga.ca/aboutus/LGArchivist/v2.htm\#news.

16 Canadian Lesbian and Gay Archives, "Volunteers," Lesbian and Gay Archivist No. 11 (February 1995), accessed April 12, 2012, http://www.clga.ca/aboutus/LGArchivist/v11.htm.

17 Canadian Gay Archives, "New Publication," Gay Archivist No.10 (November 
1992). Accessed April 12, 2012.

http://www.clga.ca/aboutus/LGArchivist/v10.htm.

18 Canadian Gay Archives, "Problems With Research in Gay History."

19 Canadian Gay Archives, "Photograph Collection," Gay Archivist No. 2 (May 1978), accessed April 12, 2012, http://www.clga.ca/aboutus/LGArchivist/v2.htm\#news. Canadian Gay Archives, "Tape Collection," Gay Archivist No. 2 (May 1978), accessed April 12, 2012, http://www.clga.ca/aboutus/LGArchivist/v2.htm\#news.

20 Canadian Gay Archives, "Recovery."

21 Canadian Gay Archives, "Public Accessibility," Gay Archivist No. 4 (November 1981), accessed April 14, 2012. http://www.clga.ca/aboutus/LGArchivist/v4.htm\#projects.

22 Beyond analyzing the CLGA's conceptualization of "Canadian" as conveyed in their newsletter, it is also important to acknowledge that the organization also actively constructs the "Canadian" LGBT historical record by virtue of its national mandate. As one anonymous reviewer of this paper highlighted, the national mandate of the CLGA does not reflect that other regional collections across Canada are often more accessible to researchers and are sometimes more actively engaged in collecting regional-specific content. Regional-specific mandates, such as the queer holdings at the University of Manitoba Special Collections; the Saskatchewan Archives Board; the University of Saskatchewan Special Collections; and those in the City of Edmonton Archives.

23 Canadian Lesbian and Gay Archives, "The Gay Periodical Press in Eastern Europe," Lesbian and Gay Archivist No. 11 (February 1995), accessed April 12, 2012, http://www.clga.ca/aboutus/LGArchivist/v11.htm.

24 Canadian Gay Archives, "Problems with Research in Gay History."

25 Canadian Gay Archives, "Whitman in Ontario," Gay Archivist No. 4 (November 1981), accessed April 14, 2012.

http://www.clga.ca/aboutus/LGArchivist/v4.htm\#projects. Canadian Lesbian and Gay Archives, "Recovery."

26 Canadian Gay Archives, "Problems with Research in Gay History."

27 Canadian Gay Archives, "Recovery."

28 Canadian Gay Archives, "Problems with Research in Gay History."

29 Ibid.

30 Canadian Gay Archives, "Problems with Research in Gay History."

31 Canadian Gay Archives, "Gays in New France," Gay Archivist No. 2 (May 1978), accessed April 12, 2012, http://www.clga.ca/aboutus/LGArchivist/v2.htm\#news.

32 Canadian Gay Archives, "News Items." 
33 Canadian Gay Archives, "Recovery."

34 Canadian Gay Archives, "Whitman in Ontario."

35 Canadian Gay Archives, "Recovery." Canadian Gay Archives, "Gays in New France."

36 Canadian Gay Archives, "News Items." Canadian Gay Archives, "Whitman in Ontario."

37 Canadian Gay Archives, "Problems with Research in Gay History."

38 Canadian Gay Archives, "Gays in New France."

39 Canadian Gay Archives, "News Items."

40 Canadian Gay Archives, "Archives in its Fourth Year," Gay Archivist No.1 (May 1977), accessed April 12, 2012,

http://www.clga.ca/aboutus/LGArchivist/v1.htm.

41 Canadian Gay Archives, "Incorporation," Gay Archivist No. 4 (November 1981), accessed April 14, 2012.

http://www.clga.ca/aboutus/LGArchivist/v4.htm\#projects.

42 Ibid.

43 Canadian Gay Archives, "80 ${ }^{\text {th }}$ Anniversary," Gay Archivist No.1 (May 1977), accessed April 12, 2012, http://www.clga.ca/aboutus/LGArchivist/v1.htm.

44 Canadian Gay Archives, "Problems with Research in Gay History."

45 Canadian Gay Archives, "Our Silver Anniversary: Canadians Have Been Organizing for 25 Years!” Gay Archivist No.7 (June 1989), accessed April 15, 2012. http://www.clga.ca/aboutus/LGArchivist/v7.htm.

46 Canadian Gay Archives, "The Record of AIDS," Gay Archivist No. 10

(November 1992), accessed April 12, 2012.

http:/ /www.clga.ca/aboutus/LGArchivist/v10.htm.

47 Canadian Gay Archives, "Our Silver Anniversary."

48 Rick Bebout, "Stashing the Evidence," The Body Politic No. 55 (August 1979):

21-22, 26. LGBT Life with Full Text, EBSCOhost (accessed April 12, 2012).

49 Canadian Lesbian and Gay Archives, "Out of the Archives: Oscar Wilde,"

Lesbian and Gay Archivist No. 11 (February 1995), accessed April 12, 2012, http://www.clga.ca/aboutus/LGArchivist/v11.htm.

50 Canadian Gay Archives, "Gays in New France." Canadian Gay Archives, "Recovery."

51 Canadian Gay Archives, "Our Silver Anniversary."

52 Canadian Gay Archives, "Remembering the Right to Privacy Commission,"

Gay Archivist No. 9 (June 1991), accessed April 14, 2012,

http://www.clga.ca/aboutus/LGArchivist/v9.htm.

53 Ibid. 
54 Canadian Gay Archives, "The Archivist at Work," Gay Archivist No. 9 (June 1991), accessed April 14, 2012, http://www.clga.ca/aboutus/LGArchivist/v9.htm.

55 Ibid.

56 Canadian Gay Archives, "Reorganization and Renewal at the CGA," Gay Archivist No. 10 (November 1992), accessed April 12, 2012. http://www.clga.ca/aboutus/LGArchivist/v10.htm.

57 Canadian Lesbian and Gay Archives, "Building the New Archives" Lesbian and Gay Archivist No. 11 (February 1995), accessed April 12, 2012, http://www.clga.ca/aboutus/LGArchivist/v11.htm.

58 Tom Warner, Never Going Back: A History of Queer Activism in Canada (Toronto: University of Toronto Press, 2002).

59 Don McLeod, Lesbian and Gay Liberation in Canada: A Selected Annotated Chronology, 1964-1975 (Toronto: ECW Press/Homewood Books, 1996): 45-46, 136, 251.

60 Kate Eichhorn, The archival turn in feminism: Outrage in order (Philadelphia: Temple University Press, 2013), 32.

61 Eichhorn, 43.

62 Cvetkovich, 245.

63 Lisa Duggan, The Incredible Shrinking Public: Sexual Politics and the Decline of Democracy, (Boston: Beacon Press, 2002), 179. 